\title{
VARIASI LEKSIKAL BAHASA SUNDA DI PROVINSI LAMPUNG: KAJIAN DIALEKTOLOGI
}

\author{
Mukhammad Isnaeni ${ }^{1}$, Multamia RMT Lauder ${ }^{2}$ \\ ${ }^{12}$ Fakultas Ilmu Pengetahuan Budaya, Universitas Indonesia \\ Pos-el: isnaeni.mhd@gmail.com ${ }^{1}$, mia.lauder@gmail.com²
}

\begin{abstract}
Abstrak
Penelitian ini bertujuan untuk mendeskripsikan persebaran variasi leksikal bahasa Sunda di Provinsi lampung. Untuk mengetahui persebarannya, peneliti menggunakan metode pupuan lapangan sebagai teknik pengumpulan data. Data penelitian dikumpulkan dengan menggunakan daftar tanyaan dialektologi yang sudah dibakukan dan divalidasi oleh Badan Pengembangan dan Pembinaan Bahasa, Kemdikbud, yang berisi 200 kosakata dasar Swadesh dan 343 kosakata budaya dasar yang terdiri dari 52 kosakata bagian tubuh, 25 kosakata sistem kekerabatan, 98 kosakata gerak dan kerja, 52 kosakata bilangan, 48 kosakata rumah dan bagiannya, dan 68 kosakata tanaman, halaman, dan pepohonan. Hasil analisis dari 200 kosakata dasar Swadesh dan 52 bagian tubuh menunjukkan bahwa variasi leksikal bahasa Sunda yang ada di Provinsi Lampung memperlihatkan distribusi paling tinggi untuk kelompok satu etimon dengan jumlah 129 glos. Variasi untuk kelompok satu etimon ini lebih tepat disebut variasi fonologis karena masih berasal dari satu etima. Selanjutnya adalah kelompok dua etimon dengan 87 glos, kelompok tiga etimon dengan 30 glos, kelompok empat etimon dengan 6 glos dan kelompok lima etimon dengan 1 glos yang teridentifikasi.
\end{abstract}

Keywords: variasi leksikal, dialektologi, glos, etimon, bahasa Sunda.

\begin{abstract}
This study aimed to describe the distribution of lexical variations of Sundanese in Lampung Province. To determine the distribution, researchers used the field survey method as a data collection technique. The data were collected by using a standardized dialectological questionnaire composed by National Language Centre (Badan Bahasa) which contains Swadesh's 200-word list and 343 cultural words consisting of 52-word list in parts of body, 25-word list in kinship, 98-word list in action verbs, 52-word list in figures, 48 -word list in house and its parts, and 68word list in plants, yard, and trees. The results of the analysis of Swadesh's 200word list and 52-word list in parts of the body suggested some lexical variations. They were grouped based on its etyma: one etymon with 129 gloss, two etyma with 87 gloss, three etyma with 30 gloss, four etyma with 6 gloss and five etyma with 1 gloss.
\end{abstract}

Keywords: lexical variation, dialectology, gloss, etymon, Sundanese

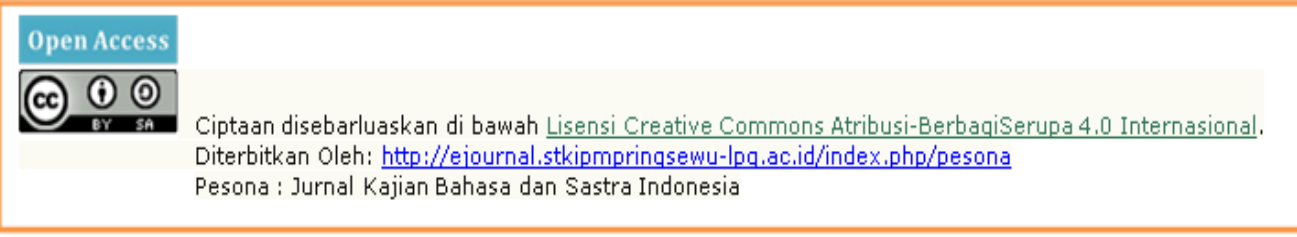




\section{PENDAHULUAN}

Suku Sunda adalah suku bangsa terbanyak ketiga yang mendiami Provinsi Lampung, jumlahnya hampir sama dengan penduduk asli Lampung. Suku Sunda sebagai suku pendatang menempati posisi kedua setelah suku Jawa. Banyaknya pendatang yang menghuni sebagian besar wilayah Provinsi Lampung menandakan bahwa masyarakat Lampung sangat menerima dan menghargai pendatang walaupun pendatang tersebut berasal dari suku yang berlainan dengan mereka. Banyaknya pendatang yang menghuni Provinsi Lampung tidak terlepas dari program transmigrasi yang sudah digalakkan sejak zaman dahulu. Banyaknya pendatang yang bermigrasi dan menghuni Provinsi Lampung membawa pengaruh dalam kehidupan berbahasa masyarakatnya. Sebagian besar masyarakat Lampung menguasai lebih dari satu bahasa. Mereka sebagian besar dapat menggunakan bahasa ibu dan bahasa Indonesia silih berganti dalam kehidupan sehari-hari. Bahkan, banyak masyarakat, terutama mereka yang tinggal di wilayah geografis yang berbatasan dengan desa yang menggunakan bahasa daerah yang berbeda, dapat menggunakan lebih dari 2 bahasa. Artinya, selain menguasai bahasa ibu sebagai bahasa pertama dan bahasa Indonesia, mereka juga menguasai bahasa daerah lainnya.
Para pendatang, termasuk suku Sunda, menyebar dan dan tinggal di hampir seluruh wilayah Provinsi Lampung dengan membawa bahasa daerah dan dialeknya masing-masing. Orang Jawa tinggal di perkampungan orang Jawa, orang Sunda tinggal di perkampuangan orang Sunda, dan orang Bali juga tinggal di perkampungan Bali. Akan tetapi, walaupun mereka datang dengan membentuk sebuah perkampungan baru dari sukunya masing-masing, perkampungan mereka letaknya biasanya berdekatan atau bersebelahan dengan masyarakat suku lainnya. Hal ini menyebabkan kerap terjadinya kontak antara penduduk yang berlainan suku bangsa dan bahasanya. Mobilitas mereka terutama dilakukan antarwilayah yang berdekatan sehingga terjadi kontak bahasa.

Setakat ini, penelitian dialektologi yang fokus mengkaji distribusi variasi bahasa Sunda di Provinsi Lampung belum banyak, bahkan belum pernah dilakukan. Suprayogi (2017) melakukan kajian dialektologi di Kabupaten Pringsewu Provinsi Lampung. Hasil penelitiannya menunjukkan bahwa Kabupaten Pringsewu memiliki situasi kebahasaan yang kompleks dengan empat bahasa (Jawa, Lampung, Sunda, dan Semendo) yang tersebar dengan pola-pola yang rumit karena tidak berpusat pada blok wilayah tertentu. Empat bahasa tersebut memiliki fitur-fitur yang khas, 
dengan kedekatan antarbahasa yang beragam karena pengaruh kontak bahasa dan Proto Austronesia dan Proto WestMalayo Polynesia. Bahasa-bahasa yang bermigrasi ke wilayah Pringsewu telah menjauhi pusatnya dan saling mempengaruhi bahasa setempat sehingga menjadi salah satu alasan hasil perhitungan dialektometri menunjukkan status beda dialek, selain karena faktor warisan bersama. Beberapa data juga menunjukkan adanya korespondensi bunyi pada beberapa kosakata yang diperbandingkan dari empat bahasa tadi.

Jika Suprayogi fokus mengkaji variasi bahasa yang ada di Kabupaten Pringsewu, Kurniawati (2007) mencoba melakukan kajian dialektologi yang lebih luas cakupannya yakni Provinsi Lampung. Tujuannya adalah untuk mengetahui dialekdialek Bahasa Lampung, di tengah banyaknya versi atau sumber tentang pembagian dialek dan subdialek bahasa Lampung. Temuan penelitian menunjukkan bahwa hanya terdapat dua dialek bahasa Lampung, yakni dialek Pesisir (terdiri dari subdialek Pesisir dan subdialek Pubian) dan dialek Abung. Unsur-unsur relik yang ditemukan menunjukkan kedekatan bahasa Lampung dengan Proto Austronesia. Selain itu, ditemukan pula bahwa di Lampung terdapat 10 bahasa, yakni bahasa Jawa, Bali,
Semende, Ogan, Bugis, Pegagan, Sunda, Komering, Basemah dan Lampung.

Berbeda dengan Kurniawati (2007) dan Suprayogi (2017), Zawarnis (2009) menulis "Variasi Dialektal Bahasa Jawa di Lampung". Tesis ini merupakan kajian dialektologi tentang bahasa-bahasa Jawa yang berkembang di Provinsi Lampung. Hasil penelitian ini menunjukkan bahwa bahasa Jawa di Lampung memiliki perbedaan pada tingkat subdialek saja.

Berbagai kajian tentang kontak bahasa juga sudah banyak dilakukan dalam penelitian dialektologi, salah satunya oleh Vathira (2013) yang menulis tesis berjudul "Geografi Dialek Bahasa Melayu Riau di Kabupaten Rokan Hulu: Suatu Kajian Dialektologi”. Hasil penelitian ini menunjukkan bahwa di kabupaten ini terdapat satu bahasa, yakni Bahasa Melayu dengan dua dialek - Dialek Melayu Rokan Hulu dan Dialek Melayu Mandailing. Ditemukan empat pola sebar berian yang menunjukkan kontak bahasa pada tataran leksikal bahasa Melayu Rokan Hulu.

Ayatrohaedi (1978) melakukan kajian dialektologi mengenai bahasa Sunda di daerah Cirebon. Tujuannya adalah untuk melihat seberapa jauh pengaruh Bahasa Jawa Cirebon (BJC) terhadap bahasa Sunda di daerah Cirebon (BSC) terutama pada bidang kosakata karena di daerah Cirebon dikenal dua bahasa daerah, yaitu BSC dan 
BJC. Pada umumnya kedua bahasa tersebut digunakan oleh penduduk daerah tertentu secara terpisah. Penelitian Ayatrohaedi menggunakan teori dialektologi dengan menggunakan alat bantu garis watas kata, dan penghitungan dialektometri. Hasil penelitian Ayatrohaedi menyimpulkan bahwa (1) BJC banyak mempengaruhi BSC pada hal-hal yang bertalian dengan hidup sehari-hari seperti pada nama-nama bagian rumah, tanaman, anggota badan, system kekerabatan, makanan dan minuman, system pemerintahan dan bagian-bagian alam, (2) Selain terkena pengaruh BJC, BSC juga terkena pengaruh Bahasa Jawa dan bahasa lainnya.

Mulatsih (2016) melakukan penelitian dialektologi bahasa Sunda di daerah Serang, Provinsi Banten untuk menemukan bentuk inovasi bahasa Sunda yang dipakai oleh masyarakat di Kampung Puyuh Koneng. Hampir sama dengan apa yang dilakukan oleh Ayatrohaedi, Mulatsih juga meneliti pengaruh bahasa Jawa ke dalam tuturan bahasa Sunda untuk mengetahui inovasi bentuk berupa inovasi leksikal dan inovasi fonetis yang terjadi pada penggunaan bahasa Sunda di Kampung Puyuh Koneng. Hasil penelitiannya menunjukkan bahwa bahasa Sunda di wilayah tersebut mengaami inovasi bentuk berupa inovasi leksikal penuh dan inovasi fonetis yang menjadi ciri khas pembeda dengan dialek bahasa Sunda lainnya.

Pembagian dialek bahasa Sunda pertama kali dikemukakan oleh Satjadibrata (1960). Menurut Satjadibrata (1960) dalam Darpan (2008) bahasa Sunda mempunyai sembilan buah dialek atau variasi, yaitu: (1) dialek Bandung, (2) dialek Banten, (3) dialek Cianjur, (4) dialek Purwakarta, (5) dialek Cirebon, (6) dialek Kuningan, (7) dialek Sumedang, (8) dialek Garut, dan (9) dialek Ciamis. Dari kesembilan dialek tersebut yang dijadikan bahasa Sunda standar atau lulugu adalah bahasa Sunda dialek Bandung yang banyak digunakan dan diajarkan di sekolah-sekolah. Penamaan dialek-dialek tersebut didasarkan pada daerah pemakaian ragam bahasa tersebut.

Hal ini berbeda dengan apa yang dilakukan oleh Pusat Bahasa (2008) yang membagi dialek bahasa Sunda ke dalam tiga dialek, yaitu (1) dialek [h], (2) dialek non-[h], dan (3) dialek o. Dengan menggunakan penghitungan dialektometri, tim Badan Bahasa menemukan perbedaan antara ketiga dialek tersebut sebesar $60 \%$. Dialek [h] dituturkan hampir di seluruh wilayah Jawa Barat dan Banten (kecuali wilayah Pesisir Utara), antara lain Majalengka, Bogor, Tasikmalaya, Kuningan, Bekasi, Garut, Ciamis Tangerang, Sukabumi, Subang, Purwakarta, Sumedang, Cianjur, Karawang, Serang, 
Lebak, Bandung, Pandegalang, dan Cirebon. Dialek ini merupakan dialek standar karena di samping digunakan di pusat pemerintahan, sebaran geografisnya luas, jumlah penuturnya lebih besar, juga digunakan dalam media massa cetak dan elektronik. Pada dialek [h] ini terdapat realisasi bunyi [h] di segala posisi sebagai mana bahasa Sunda baku pada umumnya.

Dari beberapa penelitian yang sudah disebutkan tersebut di atas, tidak ada satu pun yang secara khusus mengkaji variasi bahasa Sunda, khususnya sebaran-sebaran kosakata bahasa Sunda di Provinsi Lampung. Sudah ada beberapa penelitian dialektologi yang dilakukan di berbagai daerah di Indonesia. Akan tetapi, sebagian besar penelitian tersebut dilakukan di wilayah bahasa itu lahir, tumbuh, dan berkembang, dan bukan di luar wilayah asalnya atau homeland-nya. Oleh kerena itu, berdasarkan penjelasan di atas, penelitian dialektologi mengenai bahasa Sunda khususnya Bahasa Sunda yang hidup di luar homeland-nya penting dan relevan untuk dilakukan. Hal inilah yang menjadikan kebaruan (novelty) dari penelitian ini.

Penutur bahasa daerah di Lampung hidup berkelompok. Orang Jawa tinggal di perkampungan Jawa, orang Sunda hidup berkelompok dengan sesama Sunda, dan orang Bali juga banyak yang bermukim di perkampungan Bali. Akan tetapi, tiap kelompok itu wilayahnya berdekatan satu sama lain. Hal ini menyebabkan sering terjadinya kontak antara penduduk yang berlainan bahasanya dan mampu menguasai lebih dari satu bahasa daerah. Dalam wilayah yang multilingual seperti ini sangat besar kemungkinan terjadinya akomodasi bahasa. Melalui akomodasi ini, seorang penutur berusaha untuk menjadi anggota kelompok dari sebuah masyarakat tutur. Adakalanya, dari akomodasi bahasa itu akan muncul dialek-dialek atau bahkan bahasabahasa baru yang sama sekali berbeda dengan bahasa aslinya.

Selain faktor dalam-bahasa, faktor luar-bahasa juga sangat menentukan pertumbuhan dan perkembangan dialek. Keadaan alam, misalnya, dapat mempengaruhi ruang gerak penduduk setempat, baik dalam hal mempermudah penduduk berinteraksi atau berkomunikasi maupun mempersulit terjadinya komunikasi tersebut. Di samping itu, terjadinya keberagaman dialek juga dapat disebakan karena hubungan dan keunggulan bahasa yang terbawa ketika terjadi perpindahan penduduk, penyerbuan, atau penjajahan. Peranan dialek atau bahasa yang bertetangga juga menentukan terbentuknya dialek atau bahasa baru. Dialek dan bahasa yang bertetangga itu masuk ke dalam dialek atau bahasa baru bisa dalam bentuk 
kosakata, struktur, dan cara pengucapan atau lafal (Guiraud, 1970).

Berkaitan dengan hal di atas, kontak bahasa yang terjadi di daerah transmigrasi yang corak masyarakatnya saling hidup berdampingan sangat menarik untuk dijadikan objek penelitian dialektologi, terutama mengenai ada tidaknya variasi leksikal yang dihasilkan dari kontak bahasa tersebut. Oleh karena itu, untuk membatasi permasalahan agar tetap fokus dan tidak melebar, pertanyaan penelitian dalam penelitian ini adalah bagaimanakah persebaran variasi leksikal Bahasa Sunda yang ada di Provinsi Lampung.

\section{METODE PENELITIAN}

Penelitian ini adalah penelitian lapangan dengan menggunakan ancangan kualitatif untuk menggambarkan jenis-jenis perbedaan atau variasi leksikal yang ditemukan pada titik pengamatan (TP) yang berbahasa Sunda. Data penelitian dikumpulkan dengan menggunakan daftar tanyaan dialektologi yang sudah dibakukan dan divalidasi oleh Badan Pengembangan dan Pembinaan Bahasa, Kemdikbud. Daftar tanyaan berisi pertanyaan 200 kosakata dasar Swadesh dan 343 kosakata budaya dasar, yang terdiri dari 52 kosakata bagian tubuh, 25 kosakata sistem kekerabatan, 98 kosakata gerak dan kerja, 52 kosakata bilangan, 48 kosakata rumah dan bagiannya, dan 68 kosakata tanaman, halaman, dan pepohonan.

Data dijaring dari para informan dengan menggunakan teknik pupuan lapangan (Ayatrohaedi, 1985) yang dapat dilakukan dengan cara menanyakan langsung atau tak langsung, memancing jawaban, dan mengulang atau mengkonfirmasi jawaban informan. Data informan direkam dan ditranskripsikan dengan menggunakan lambang fonetis. Jumlah informan yang berpartisipasi pada penelitian ini berjumlah 15 informan dari berbagai kabupaten di Provinsi Lampung. Informan dipilih dengan kriteria sebagai berikut: a) berjenis kelamin pria/wanita; b) berusia antara 25-45 tahun; c) lahir dan besar di titik pengamatan; d) berpendidikan SD atau SMP; e) bermobilitas rendah; f) pekerjaannya petani atau buruh; dan g) tidak cacat organ bicaranya.

Data yang sudah ditranskripsikan selanjutnya dianalisis dengan menggunakan teknik pemetaan, berkas isogloss, dan perhitungan dialektometri (Lauder, 2007). Selanjutnya, data akan disajikan dengan menggunakan data-data kualitatif berupa variasi-variasi leksikal yang muncul pada bahasa Sunda, khususnya untuk 200 kosakata dasar Swadesh dan 52 kosakata budaya dasar bagian tubuh. 


\section{HASIL DAN PEMBAHASAN}

Distribusi variasi leksikal Bahasa Sunda pada penelitian ini dihasilkan dari daftar tanyaan yang berisi 200 kosakata dasar Swadesh dan 52 kosakata budaya dasar bagian tubuh. Distribusi variasi leksikal tersebut dikelompokkan berdasarkan jumlah etimon sebagai berikut.

Tabel 1. Distribusi variasi leksikal berdasarkan etimon

\begin{tabular}{|l|c|}
\hline \multicolumn{1}{|c|}{ Etimon } & Jumlah glos \\
\hline Satu Etimon* & 129 \\
\hline Dua Etimon & 87 \\
\hline Tiga Etimon & 30 \\
\hline Empat Etimon & 6 \\
\hline Lima Etimon & 1 \\
\hline
\end{tabular}

*variasi fonologis

Dari tabel 1 terlihat bahwa variasi leksikal Bahasa Sunda yang ada di Provinsi Lampung memperlihatkan distribusi paling tinggi untuk kelompok satu etimon dengan jumlah 129 glos. Variasi untuk kelompok satu etimon ini lebih tepat disebut variasi fonologis karena masih berasal dari satu etima. Selanjutnya adalah kelompok dua etimon dengan 87 glos, kelompok tiga etimon dengan 30 glos, kelompok empat etimon dengan 6 glos dan terakhir kelompok lima etimon dengan 1 glos yang teridentifikasi. Semua temuan ini bersumber dari daftar tanyaan berupa 200 kosakata dasar Swadesh dan 52 kosakata budaya dasar bagian tubuh. Selanjutnya, untuk memperjelas variasi yang muncul, tiap-tiap kelompok etimon akan dikelompokkan lagi berdasarkan pada jumlah pelambang sehingga distribusinya akan terlihat seperti pada penjelasan berikut ini.

\section{Kelompok Satu Etimon}

Perbedaan yang muncul dari kelompok ini tidak memiliki variasi secara leksikal karena hanya berasal dari satu etimon, namun memiliki variasi secara fonologis. Kelompok satu etimon ini disubkelompokkan lagi ke dalam jumlah pelambang yang muncul.

Tabel 2. Distribusi Variasi Leksikal Satu Etimon

\begin{tabular}{|c|c|c|}
\hline $\begin{array}{c}\text { Jumlah } \\
\text { Pelambang }\end{array}$ & $\begin{array}{c}\text { Jumlah } \\
\text { Glos }\end{array}$ & Contoh Glos \\
\hline 1 & 104 & $\begin{array}{l}\text { AKAR, ANGIN, } \\
\text { BAGAIMANA, } \\
\text { BARU, BATU, } \\
\text { BULU, BURUNG, } \\
\text { BUSUK, CACING, } \\
\text { DAGING, DAN, } \\
\text { DI MANA, DI } \\
\text { SINI, DISITU, } \\
\text { DORONG, DUA, } \\
\text { EMPAT, GARAM, } \\
\text { GIGIT, GUNUNG, } \\
\text { IKAN, JANTUNG, }\end{array}$ \\
\hline
\end{tabular}




\begin{tabular}{|c|c|c|}
\hline & & 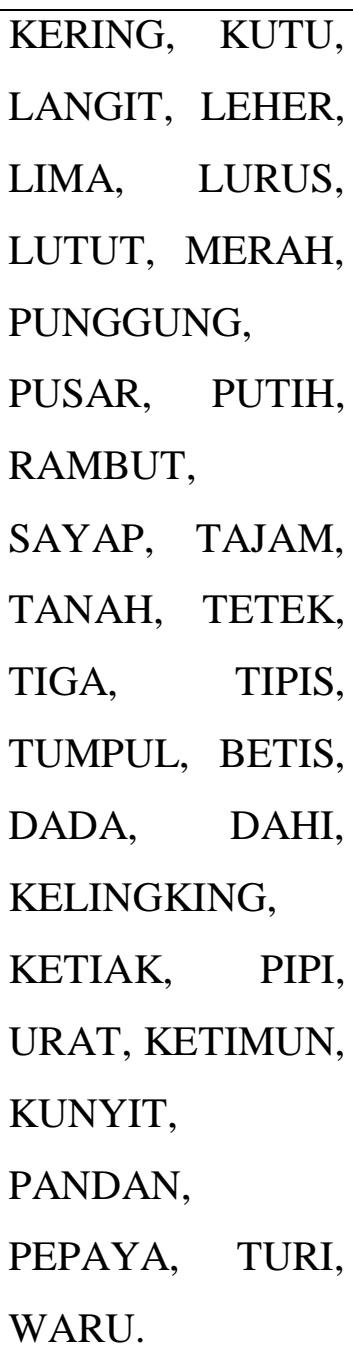 \\
\hline 2 & \begin{tabular}{|l|}
14 \\
\end{tabular} & $\begin{array}{l}\text { API, APUNG(ME), } \\
\text { BAKAR, } \\
\text { BEBERAPA, } \\
\text { BINTANG, BUAH, } \\
\text { BUNUH, } \\
\text { BURU(BER), } \\
\text { DAUN, DINGIN, } \\
\text { GARUK, GOSOK, } \\
\text { TIDAK, } \\
\text { TENGKUK }\end{array}$ \\
\hline 3 & 9 & $\begin{array}{ll}\text { AIR, } & \text { BELAH, } \\
\text { HIDUP, } & \text { HITUNG, }\end{array}$ \\
\hline
\end{tabular}

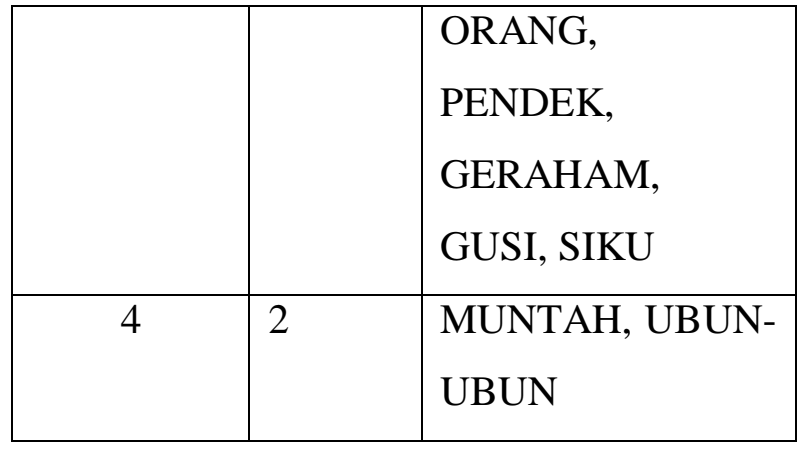

Dalam penelitian ini ditemukan 129 glos dengan satu etimon. Kelompok ini dibagi lagi menjadi kelompok satu etimon satu pelambang, satu etimon dua pelambang, satu etimon tiga pelambang, dan satu etimon empat pelambang. Dari tabel 2 tersebut dapat dilihat bahwa jumlah glos terbanyak atau yang menunjukkan distribusi tertinggi ada pada kelompok satu etimon satu pelambang. Sedangkan jumlah glos paling sedikit ada pada kelompok satu etimon empat pelambang.

\section{Kelompok Satu Etimon, Satu Pelambang}

Terdapat sekitar 104 Glos yang termasuk ke dalam kelompok ini, misalnya AKAR pada kosakata dasar Swadesh mempunyai satu pelambang [akar] yang dijumpai di semua Titik Pengamatan (TP). Tidak ada perbedaan baik itu fonologis ataupun leksikal dari glos ini. Semua informan di TP ketika ditanyakan menjawab dengan jawaban yang sama, yaitu dengan pelambang [akar]. Glos AKAR merupakan salah satu refleksi bahasa Proto Melayu 
Polinesia (PMP) yaitu *akaR dan *wakaR yang direfleksikan dalam Bahasa Sunda di semua TP pada penelitian ini. Selain dalam bahasa Sunda, bentuk proto *akaR juga direfleksikan oleh bahasa-bahasa lain di belahan bumi Indonesia, yaitu bahasa Melayu dengan pelambang [akar], bahasa Bali dengan pelambang [akah], dan bahasa Sasak di daerah timur Indonesia, dengan pelambang [akar] dan [akah] (https://www.trussel2.com/ACD/acd-

s_a1.htm). Contoh selanjutnya untuk kelompok satu etimon satu pelambang adalah TUMPUL dengan satu pelambang [mintul]. Dari TP1 hingga TP15, semua pelambang untuk glos PUTIH dilambangkan dengan pelambang yang sama, yaitu [mintul]. Pelambang [mintul] dituturkan di daerah pengamatan yang masyarakatnya mengaku berbahasa Sunda.

\section{Kelompok Satu Etimon Dua Pelambang}

Ada 14 glos yang termasuk ke dalam kelompok satu etimon dua pelambang, contohnya adalah glos API dimunculkan atau dituturkan dengan pelambang [sönö] dan [sönöP]. Pelambang [sönö?] banyak dituturkan pada TP berbahasa Sunda yang wilayahnya banyak berbatasan langsung dengan masyarakat Jawa terutama Jawa Ngapak sehingga fonem glotal /?/ banyak mempengaruhi isolek mereka. Contoh lainnya untuk kelompok satu etimon dua pelambang adalah glos BAKAR dengan pelambang [bölöm] dan [mölöm]. Pelambang [bölöm] dituturkan oleh masyarakat yang banyak dijumpai di TP bagian selatan dan timur, yaitu di Kabupaten Pesawaran, abupaten Pringsewu, dan Kabupaten Lampung Selatan. Sedangkan pelambang [mölöm] banyak dituturkan oleh masyarakat Sunda di bagian utara, yaitu di Kabupaten Lampung Tengah, Waykanan, Lampung Barat dan Pesisir Barat. Contoh selanjutnya adalah glos [BEBERAPA dengan pelambang [babaraha] dan [sabaraha] BINTANG dengan pelambang [b3ntay] dan [bintay], BUAH dengan pelambang $\left[\mathrm{bu}^{\mathrm{w}} \Lambda \mathrm{h}\right]$ dan $\left[\mathrm{b} \Lambda \mathrm{bu}{ }^{\mathrm{w}} \Lambda \mathrm{h} \Lambda \mathrm{n}\right], \mathrm{BUNUH}$ dengan pelambang [pashan] dan [mashan], BURU(BER) dengan pelambang [moro] dan [moro?], DAUN dengan pelambang [d $\Lambda$ un] dan [d $\Lambda$ n], DINGIN dengan pelambang [tiris] dan [ti?is], GARUK dengan pelambang [garo?] dan [yagarok], GOSOK dengan pelambang [gosok] dan [kəsək], TIDAK dengan pelambang [həntö] dan [əntö], TENGKUK dengan pelambang [pupunukın] dan [punduk],

\section{Kelompok Satu Etimon Tiga Pelambang}

Ada 9 glos yang termasuk ke dalam kelompok satu etimon tiga pelambang yaitu glos AIR dengan pelambang [cai] [caik] [cai?], BELAH dengan pelambang [bəlah], 
[yıbəlah], [məlah], HIDUP dengan Tabel 3. Distribusi Variasi Leksikal Dua pelambang [hurip] [urip], dan [hirup], Etimon

HITUNG dengan pelambang [ituy], [yituy], dan [3tuy], ORANG dengan pelambang [jalmi], [jəlm $\Lambda$, dan [jələm $\Lambda$ ], PENDEK dengan pelambang [pondok], [pənd3k], dan [p3nd3k], GERAHAM dengan pelambang [carsham], [baham], dan [graham], GUSI dengan pelambang [g gusi], [gugusi], dan [gusi], SIKU dengan pelambang [siku], [sisiku], dan [sikut]

\section{Kelompok Satu Etimon Empat Pelambang}

Glos yang termasuk ke dalam kelompok satu etimon tiga pelambang adalah MUNTAH dengan pelambang [utah], [uttah], [mutah] dan [muntah]. Contoh selanjutnya adalah UBUN-UBUN dengan pelambang [mun-munan], [əmbunəmbun], [əmbun-əmbunan], dan [ ${ }^{\mathrm{m}}$ bunmbunan].

\section{Kelompok Dua Etimon}

Dalam penelitian ini ditemukan beberapa glos yang termasuk dalam kelompok dua etimon. Kelompok dua etimon ini selanjutnya dikelompokkan lagi sesuai kemunculan jumlah pelambangnya. Perhatikan distribusi variasi leksikal untuk kelompok dua etimon seperti yang tertampil pada table 3 berikut ini.

\begin{tabular}{|c|c|c|}
\hline $\begin{array}{c}\text { Jumlah } \\
\text { Pelambang }\end{array}$ & $\begin{array}{c}\text { Jumlah } \\
\text { Glos }\end{array}$ & Glos \\
\hline 2 & 66 & 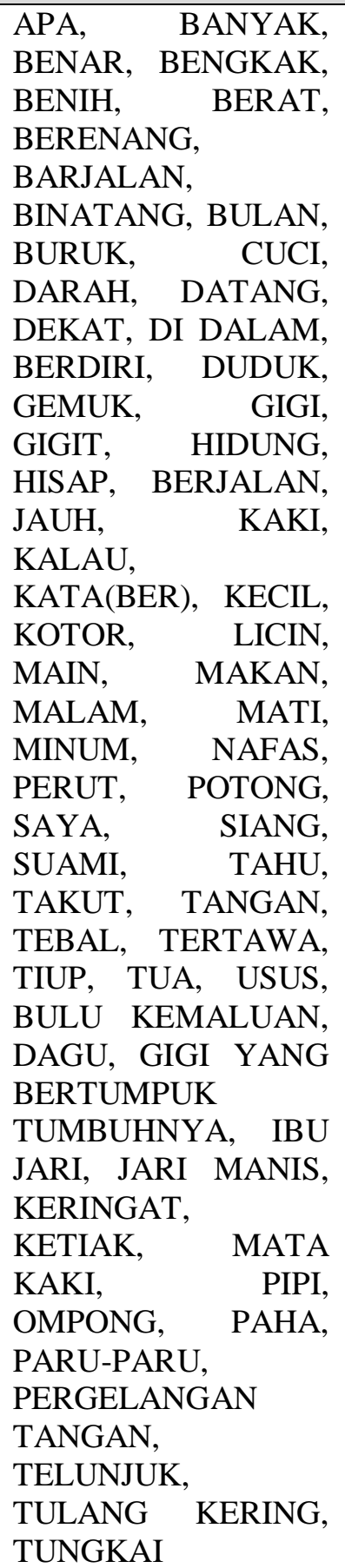 \\
\hline 3 & 15 & $\begin{array}{l}\text { ALIR, CIUM, IKAT, } \\
\text { ISTRI, } \\
\text { LIHAT, } \quad \text { PEADAH, } \\
\text { SEMUA, } \\
\text { CAMBANG, } \\
\text { KELINGKING, } \\
\text { KERONGKONGAN, }\end{array}$ \\
\hline
\end{tabular}




\begin{tabular}{|l|l|l|}
\hline & & $\begin{array}{l}\text { LANGIT-LANGIT, } \\
\text { OTAK, TUMIT }\end{array}$ \\
\hline 4 & 5 & $\begin{array}{l}\text { DEBU, IBU, JAHIT, } \\
\text { TELUR, } \\
\text { TENGAH, JARI }\end{array}$ \\
\hline 5 & 1 & JARI \\
\hline
\end{tabular}

Dalam penelitian ini ditemukan 87 glos dengan dua etimon. Kelompok dua etimon ini dibagi lagi menjadi kelompok dua etimon dua pelambang, dua etimon tiga pelambang, dua etimon empat pelambang, dan dua etimon lima pelambang. Dari tabel 3 tersebut dapat dilihat bahwa jumlah glos terbanyak atau yang menunjukkan distribusi tertinggi ada pada kelompok dua etimon dua pelambang. Sedangkan jumlah glos paling sedikit ada pada kelompok dua etimon lima pelambang.

\section{Kelompok Dua Etimon Dua Pelambang}

Ada 66 glos yang termasuk ke dalam kelompok ini. Contoh glos yang termasuk kelompok ini adalah glos APA dengan pelambang [naon] dan [kulan], BANYAK dengan pelambang [loba] dan [sö?ör], BENAR dengan pelambang [lərəs] dan [bənər], BENGKAK dengan pelambang [baröh] dan [bəyka?], BENIH dengan pelambang [bibit] dan [binih], BERAT dengan pelambang [bər $\Lambda \mathrm{t}]$ dan $[\Lambda \mathrm{bot}]$, BERENANG dengan pelambang [yəjay] dan [yebak], BERJALAN dengan pelambang [mapah] dan [lömpay], BINATANG dengan pelambang [binatan] dan [sato], BULAN dengan pelambang [bulın] dan [sısi], BURUK dengan pelambang [gorзy] dan [buruk], CUCI dengan pelambang [yumbah] dan [ñösöh], DARAH dengan pelambang [gətih] dan [mokla], DATANG dengan pelambang [dojkap] dan [rawoh], DEKAT dengan pelambang [dököt] dan [cakət], DI DALAM dengan pelambang yang muncul [dijöro?] dan [dilöböt], BERDIRI dengan pelambang [naytuy] dan [ $\left.\operatorname{yad}^{\mathrm{h}} ə \mathrm{k}\right]$, DUDUK dengan pelambang [di $\left.{ }^{\mathrm{y}} \mathrm{uk}\right]$ dan [calig], GEMUK dengan pelambang [lintuh] dan [gendut], GIGI dengan pelambang [huntu] dan [wass], GIGIT dengan pelambang [g3g3l] dan [cokst], HIDUNG dengan pelambang [iruy] dan [payambuy], HISAP dengan pelambang [isəp] dan [kəñot], BERJALAN dengan pelambang [mapah] dan [lömpay], JAUH dengan pelambang [təbih] dan [dzauh], KAKI dengan pelambang [sampe ${ }^{\mathrm{y}}$ an] dan [suku?], KALAU dengan pelambang [lamun] dan [kalo], BERKATA dengan pelambang [ñariyəs] dan [yəmon], KECIL dengan pelambang [alit] dan [lötik], KOTOR dengan pelambang [kotor] dan [bələk], LICIN dengan pelambang [13say] dan [lə?̈̈r], MAIN dengan pelambang [ulin] dan [amən], MAKAN dengan pelambang [tuwıy] dan [dahar], MALAM dengan pelambang [pötin] dan [wəyi], MATI dengan pelambang [mast] dan $[\mathrm{p} \Lambda 3 \mathrm{~h}]$, MINUM dengan pelambang [yalə?öt] dan 
[ninum], NAFAS dengan pelambang [napas] dan [ambəkan], PERUT dengan pelambang [bötöy] dan [p $\Lambda$ yatuy $\Lambda \mathrm{n}]$, POTONG dengan pelambang [t3kt3k] dan [poton], SAYA dengan pelambang [ $\Lambda$ bdi] dan [pribıdos], SIANG dengan pelambang [böray] dan [siyay], SUAMI dengan pelambang [salaki] dan [carog3], TAHU dengan pelambang [tör $\Lambda$ ] dan [ñaho?], TAKUT dengan pelambang [ $\left.\mathrm{si}^{\mathrm{y}} \mathrm{ön}\right]$ dan [mslay], TANGAN dengan pelambang [löyön] dan [panayan], TEBAL dengan pelambang [kındəl] dan [təbəl], TERTAWA dengan pelambang [söri] dan [gumujöy], TIUP dengan pelambang [ti ${ }^{\mathrm{y}} \mathrm{up}$ ] dan [kəpoh], TUA dengan pelambang [səpuh] dan [kolət], USUS dengan pelambang [usus] dan [pöjit], BULU KEMALUAN dengan pelambang [jombut] dan [b $\lrcorner$ ok], DAGU dengan pelambang

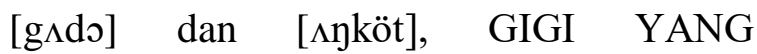
BERTUMPUK TUMBUHNYA dengan pelambang [karshol] dan [ginsul], IBU JARI dengan pelambang [jompsl] dan [induyləyön], JARI MANIS dengan pelambang [calincin] dan [jیrimınis], KERINGAT dengan pelambang [k3s $\Lambda \mathrm{y}]$ dan [krijət], KETIAK dengan pelambang [k3lsk] dan [k3t3k], MATA KAKI dengan pelambang [mumuncayan] dan [m $\Lambda \mathrm{t} \Lambda \mathrm{k} \Lambda \mathrm{ki}]$, PIPI dengan pelambang [pipi] dan [d $\Lambda$ mis], OMPONG dengan pelambang [ompoy] dan [pohıy], PAHA dengan pelambang $[\mathrm{p} \Lambda \mathrm{h} \Lambda]$ dan [pinpin], PARU-PARU dengan pelambang [paruparu] dan [bayah], PERGELANGAN TANGAN dengan pelambang [ugəlugəl] dan [pigəl $\Lambda$ ], TELUNJUK denagn pelambang [curu?] dan [təlunjuk], TULANG KERING dengan pelambang [bincur $\wedge$ ] dan [tulıy g grin], TUNGKAI dengan pelambang [tatapakan] dan [dampal]

\section{Kelompok Dua Etimon Tiga Pelambang}

Ada 15 glos yang termasuk ke dalam kelompok ini. Contohnya adalah glos ALIR dengan pelambang [yalIr] [yalsr] [yəcor], CIUM dengan pelambang [asun], [sun], [ñium], IKAT denagan pelambang [böyköt], [taliyan], dan [tali], ISTRI dengan pelambang [carog3], [pamajikan], dan [istri], LIDAH dengan pelambang [list $\mathrm{h}]$, [lid $\Lambda \mathrm{h}]$, dan [il $\Lambda \mathrm{t}$, LIHAT dengan pelambang [tinali], [ninali], dan [ ${ }^{\mathrm{n}}$ delo?], PEGANG dengan pelambang [cəkəl], [cəpəy], dan [cәpə犭an], SEMUA dengan pelambang [ $\operatorname{s} \Lambda \mathrm{d} \Lambda \mathrm{y} \Lambda \mathrm{n} \Lambda],[\mathrm{k} \wedge \mathrm{b} 3 \mathrm{~h}]$, dan [k$\wedge \mathrm{b} 3 \mathrm{han}]$, BIBIR dengan pelambang [biwir], [lambзy], dan [lamsy], CAMBANG dengan pelambang [cambay], [sambay], dan [god3k], KELINGKING dengan pelambang [cingir], [cinir], [kəlinkin], KERONGKONGAN dengan pelambang [tikəroP], [kərəykəy $\Lambda \mathrm{n}]$ dan [kırəykəyın], LANGIT-LANGIT

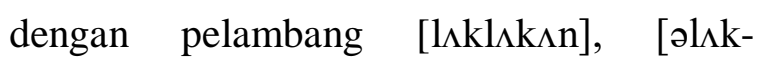

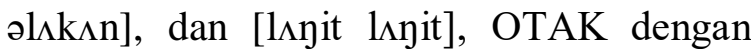


pelambang [ot $\Lambda \mathrm{k}]$, [utək], dan [polっ?], TUMIT dengan pelambang [könön], [tumit] dan [timit]

\section{Kelompok Dua Etimon Empat Pelambang}

Ada 5 glos yang termasuk ke dalam kelompok ini. Contohnya adalah glos DEBU yang mempunyai empat pelambang, yaitu [kəkəbul], [kəbul], [yəbul], [ləbu]. Selanjutnya glos IBU dengan pelambang [əma?], [ma?], [ambu], dan [ibu]. Glos JAHIT juga mempunyai 4 pelambang yaitu [jahit], [jait], [kaput], dan [yaput]. Contoh selanjutnya adalah glos TELUR dengan pelambang [əndəg], [ ${ }^{\mathrm{n}} \mathrm{d}$ gg], [təlUr], dan [təlor] dan glos JARI TENGAH dengan pelambang [jaykuy], [jajaykuy], [jəjaykuy, dan [jari təjah]

\section{Kelompok Dua Etimon Lima Pelambang}

Ada 1 glos yang termasuk dalam kelompok ini, yaitu glos JARI dengan pelambang [r $\Lambda \mathrm{mo}$ ], $[\mathrm{r} 3 \mathrm{~m} \Lambda$ ], [j $\Lambda \mathrm{ri}]$, [jəriji], [driji]

\section{Kelompok Tiga Etimon}

Dalam penelitian ini ditemukan beberapa glos yang termasuk dalam kelompok tiga etimon. Kelompok tiga etimon ini selanjutnya dikelompokkan lagi sesuai kemunculan jumlah pelambangnya seperti yang tertera dalam tabel 4 berikut ini.
Tabel 4. Distribusi Variasi Leksikal Tiga Etimon

\begin{tabular}{|c|c|c|}
\hline $\begin{array}{c}\text { Jumlah } \\
\text { Pelambang }\end{array}$ & $\begin{array}{c}\text { Jumlah } \\
\text { Glos }\end{array}$ & Glos \\
\hline 3 & 23 & 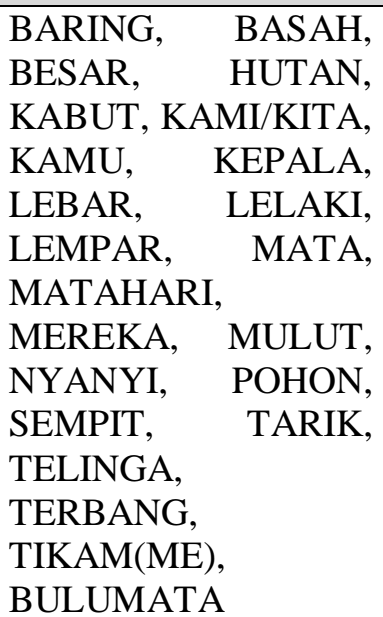 \\
\hline 4 & 6 & $\begin{array}{l}\text { DANAU, } \\
\text { NAMA, } \\
\text { TIDUR, }\end{array}$ \\
\hline 5 & 1 & BUNGA \\
\hline
\end{tabular}

Dalam penelitian ini ditemukan 30 glos dengan tiga etimon. Kelompok tiga etimon ini dibagi lagi menjadi kelompok tiga etimon tiga pelambang, tiga etimon empat pelambang dan tiga etimon lima pelambang. Dari tabel 4 tersebut dapat dilihat bahwa jumlah glos terbanyak atau yang menunjukkan distribusi tertinggi ada pada kelompok tiga etimon tiga pelambang. Sedangkan jumlah glos paling sedikit ada pada kelompok tiga etimon lima pelambang.

\section{Kelompok Tiga Etimon Tiga pelambang}

Ada 23 glos yang teridentifikasi termasuk ke dalam kelompok ini. Glos yang termasuk ke dalam kelompok tiga etimon tiga pelambang untuk kosakata dasar Swadesh adalah BARING yang 
memunculkan pelambang [gogolзrsn], [yaləröh], dan [yod3y], BASAH dengan pelambang [b $\Lambda$ söh], [cipruk], dan [jibrək], BESAR dengan pelambang [agən], [gəd3], dan [badag], HUTAN dengan pelambang [löwöy], [utan], dan [^las]. KABUT dengan pelambang [halimun], [kabut], dan [hasəp], KAMI/KITA dengan pelambang [abdi], [uray], [kuln], KAMU dengan pelambang [mansh], [anjön], [siya?], KEPALA dengan pelambang [mıst $\Lambda \mathrm{k} \Lambda]$, [hulu], dan [sirah], LEBAR dengan pelambang $\left[\log _{\Lambda}\right]$, [l3bar], dan [rub $\Lambda$ k], LELAKI dengan pelambang [lalaki?], [lanay], dan [paməgöt], LEMPAR dengan pelambang [balsdog], [alunkön], dan

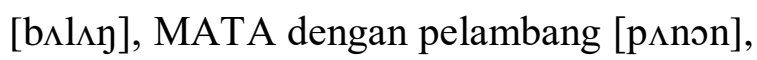
[sozs], dan [mata], MATAHARI dengan pelambang [panonpow3], [matahari], [matapow3], MEREKA dengan pelambang [maranshna], [batur], dan [barudak], MULUT dengan pelambang [suyut], [lamsy], [baham], NYANYI dengan pelambang [ñañi], [nawi], dan [nəmban], POHON dengan pelambang [tankal], [kai], dan [batan]. SEMPIT dengan pelambang [hörin], [sörög], dan [səmpit], TARIK dengan pelambang [tırlk], [bətot], dan [bədol], TELINGA dengan pelambang [cöli], [cöpil], dan [kupin], TERBANG dengan pelambang [hibər], [yapun], dan [mabor], TIKAM(ME) dengan pelambang [tujah], [tojos], dan [tusuk], BULU MATA dengan pelambang [bulu $\operatorname{ssc} \Lambda$ ], [bulu mata] dan [bulu panon],

\section{Kelompok Tiga Etimon Empat Pelambang}

Ada 6 glos yang teridentifikasi termasuk ke dalam kelompok ini. Glos yang termasuk ke dalam kelompok tiga Etimon empat pelambang untuk kosakata dasar Swadesh adalah DANAU dengan pelambang [situ], [sstu], [danau], dan [balon], IA dengan pelambang [mansh], [manshna], [anjön], dan [ñak], LAIN dengan pelambang [sanзs], [lain], [la3n], [sзj3n], NAMA dengan pelambang [nami], [ $\Lambda$ ran], [y $\Lambda$ ran], dan [jeneyan], SEDIKIT dengan pelambang [sakədi?], [sastik], [saAlit] dan [səkədik], TIDUR dengan pelambang [sır3], [kuləm], [uləm], dan [h3?3s].

\section{Kelompok Tiga Etimon Lima Pelambang}

Ada 1 glos yang teridentifikasi termasuk ke dalam kelompok ini. Glos yang termasuk ke dalam kelompok tiga etimon lima pelambang untuk kosakata dasar Swadesh adalah BUNGA dengan

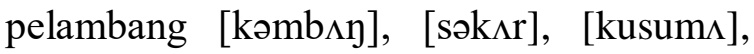
[kəsuma], dan [kesumı?]

\section{Kelompok Empat Etimon}

Dalam penelitian ini ditemukan beberapa glos yang termasuk dalam 
kelompok empat Etimon seperti yang tercantum dalam tabel di bawah ini.

Tabel 5. Distribusi Variasi Leksikal Empat Etimon

\begin{tabular}{|c|c|c|}
\hline $\begin{array}{c}\text { Jumlah } \\
\text { Pelambang }\end{array}$ & $\begin{array}{c}\text { Jumlah } \\
\text { Glos }\end{array}$ & Glos \\
\hline 4 & 5 & $\begin{array}{l}\text { JATUH, } \\
\text { PEREMPUAN, } \\
\text { SUNGAI, GIGI YANG } \\
\text { MENONJOL } \\
\text { KELUAR, } \\
\text { KEMALUAN LAKI- } \\
\text { LAKI }\end{array}$ \\
\hline 5 & 1 & HANTAM \\
\hline
\end{tabular}

Dari tabel 5 terlihat bahwa terdapat 6 glos yang termasuk ke dalam kelompok empat etimon, yang terbagi lagi menjadi kelompok empat etimon empat pelambang dan empat etimon lima pelambang.

Kelompok Empat Etimon Empat Pelambang

Ada 5 glos yang termasuk ke dalam kelompok empat etimon empat pelambang, yaitu glos JATUH dengan pelambang [labuh], [gebis], [murak], dan [ragak], PEREMPUAN dengan pelambang [ $\Lambda$ W $3 \mathrm{~W} 3]$, [məjıy], [istəri], dan [bikıy], SUNGAI dengan pelambang [waluy $\Lambda \mathrm{n}],[\mathrm{c} \Lambda$ igəd 3$]$, [wahay $\Lambda$ ] dan [bıyawan], GIGI YANG MENONJOL KELUAR dengan pelambang

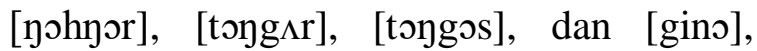
KEMALUAN LAKI-LAKI dengan pelambang [titit], [kontol], [рзрзу], dan [kınjot],
Kelompok Empat Etimon Lima Pelambang

Ada 1 glos yang termasuk ke dalam kelompok empat etimon lima pelambang yaitu glos HANTAM dengan pelambang

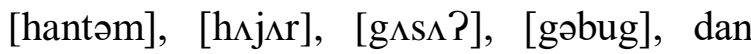
[yegəbuk],

\section{Kelompok Lima Etimon}

Penelitian ini menemukan beberapa glos yang termasuk ke dalam kelompok lima etimon seperti terlihat pada tabel berikut ini.

Tabel 6. Distribusi Variasi Leksikal Lima Etimon

\begin{tabular}{|c|c|c|}
\hline $\begin{array}{c}\text { Jumlah } \\
\text { Pelambang }\end{array}$ & $\begin{array}{c}\text { Jumlah } \\
\text { Glos }\end{array}$ & Glos \\
\hline 7 & 1 & ANAK \\
\hline
\end{tabular}

Kelompok Lima Etimon Tujuh Pelambang

Ada 1 glos yang termasuk ke dalam kelompok lima Etimon tujuh pelambang yaitu glos ANAK dengan pelambang

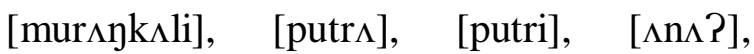
[s $\Lambda \mathrm{n} \Lambda \mathrm{P}],[\mathrm{boc} \Lambda \mathrm{h}]$, dan $[\mathrm{bud} \Lambda \mathrm{k}]$

\section{SIMPULAN}

Penelitian ini adalah penelitian penelusuran kosa kata berbahasa Sunda yang dilaksanakan di Provinsi lampung. Penelitian sejenis sudah banyak dilakukan. Akan tetapi, penelitian-penelitian tersebut biasanya dilakukan di daerah bahasa tersebut tumbuh dan berkembang. Berbeda 
dengan penelitian terdahulu, penelitian ini dilaksanakan di luar wilayahnya (homeland) nya. Dari hasil yang didapatkan diketahui bahwa variasi leksikal bahasa Sunda di Provinsi Lampung tersebar dari kelompok satu etimon hingga kelompok lima etimon. Penelitian selanjutnya masih diperlukan untuk menelusuri sejauh mana pola perubahan yang terjadi termasuk retensi dan inovasinya.

\section{DAFTAR PUSTAKA}

Ayatrohaedi. (2002). Pedoman Penelitian Dialektologi. Jakarta: Pusat Bahasa Departemen Pendidikan Nasional.

Darpan. (2008). "Satjadibrata dina Kamekaran Kamus Sunda" dalam Kamus Basa Sunda R.Satjadibrata. Bandung: Kiblat Buku Utama

https://www.trussel2.com/ACD/acds a1.htm diakses pada 30 Maret 2018.

Kantor Bahasa Provinsi Lampung. (2008). Persebaran Bahasa-bahasa di Provinsi Lampung.

Kurniawati, Wati. (2007). Mendeteksi Klasifikasi Dialek Bahasa Lampung. Unpublished materials: Tesis Universitas Indonesia

Lauder, Multamia RMT. (1993). Pemetaan Distribusi Bahasa-bahasa di Tangerang. Jakarta: Pusat Pembinaan dan Pengembangan Bahasa.

Lauder, Multamia RMT. (2007). Sekilas Mengenai Pemetaan Bahasa. Jakarta Timur: Akbar Media Aksara.
Lauder, Multamia R.M.T. and Lauder, Allan F. (2016). A Longitudinal Geolinguistic Study of Language Change in West Java, Indonesia. Eds. Jean-Michel Filippi. In Papers from the Third International Conference on Asian Geolinguistics: 1-18. Phnom Penh: Royal University of Phnom Penh.

Lauder, Multamia R.M.T. and Lauder, Allan F. (2018). A Real time geolinguitics study of language change in Bekasi, West Java. In Papers from the Fourth International Conference on Asian Geolinguistics: 4-5 May. Depok: University of Indonesia

Lembaga Bahasa Nasional. (1972). Peta Bahasa-Bahasa Indonesia. Jakarta: Direktorat Jendral Kebudayaan Departemen Pendidikan dan Kebudayaan.

Mulatsih, Devi. (2016). Inovasi Bentuk dalam Bahasa Sunda di Kampung Puyuh Koneng Desa Kencana Harapan Kecamatan Lebak Wangi Kabupaten Serang Provinsi Banten. Jurnal Logika. Vol XVII.

Pusat Bahasa. (2008). Bahasa dan Peta Bahasa di Indonesia. Jakarta: Kementerian Pendidikan dan Kebudayaan.

Suprayogi. (2017). Variasi Bahasa dan Sentuh Bahasa di Kabupaten Pringsewu: Sebuah Kajian Dialektologi. Unpublished tesis. Universitas Indonesia

Vathira, Fina. (2013). Geografi Dialek Bahasa Melayu Riau di Kabupaten Rokan Hulu: Suatu Kajian Dialektologi. Unpublished materials: Tesis Universitas Indonesia

Zawarnis, Yulfi. (2009). Variasi Dialektal Bahasa Jawa di Lampung. Unpublished materials: Universitas Indonesia. 